\title{
SYNTACTIC VARIATION IN MASORETIC HEBREW, THE OBJECT CLAUSE RECONSIDERED
}

\author{
Martijn Naaijer Dirk Roorda \\ Vrije Universiteit Amsterdam \\ Data Archiving and Networked \\ Services \\ E-mail:m.naaijer@vu.nl E-mail: dirk.roorda@dans.knaw.nl
}

(Received 16/02/2016; accepted 14/10/2016)

\begin{abstract}
In this article we reinvestigate the variation in Masoretic Hebrew of two linguistic features related to the object clause that have diachronic relevance according to various scholars. These features are the order of subject personal pronoun and nominal predicate in certain object clauses, and the variation between משר introducing the object clause. We do this by using tools provided by the SHEBANQ project. By examining as many cases as possible throughout the Masoretic Text instead of only a few exemplary cases, we analyse the extent of variation in these syntactic constructions and their relevance for linguistic dating of biblical texts.
\end{abstract}

\section{INTRODUCTION}

In their newest book on historical linguistics and Biblical Hebrew, Rezetko and Young (2014) reject the traditional approach in Hebrew linguistics in which books are grouped a priori on the basis of shared linguistic characteristics. The main point of the book is the philological approach it introduces in which linguistics and textual criticism are considered jointly. In our opinion this is an important methodological step forward. Grouping books in categories such as Early Biblical Hebrew (EBH) and Late Biblical Hebrew (LBH) and comparing other books and texts with these corpora has led to the discovery of many interesting cases of linguistic variation, ${ }^{1}$ but this

1 Many examples of features relevant for the study of diachronic variation can be found in Hurvitz (1974, 1982), and Hurvitz et al. (2014). A table of features extracted from various important works has been collected in Young, Rezetko and Ehrensvärd (2008), Volume 2, Chapter 4. Diglossia and geographic variation in Biblical Hebrew have been described extensively in the works of Gary Rendsburg (e.g., Rendsburg 1990a, 1990b, and 2002). 
approach has resulted in various problems as well. On the one hand it is difficult to compare books within each of the subcorpora of EBH and LBH. If books are classified beforehand as LBH, such as Esther and Daniel, it may seem that various linguistic features collected on the basis of the contrast with EBH are characteristic of LBH. However, very often these features occur in only one or two of the core LBH books. ${ }^{2}$ Examples of such features are the late lexemes ישכריך, both occurring תלמיד גזבר (exclusively in the book of Ezra), and (exclusively in Chronicles). ${ }^{3}$ On the other hand, the traditional approach hides similarities between the subcorpora of EBH and LBH, because the focus lies exclusively on the contrast between these groups of books. In studies working within the framework of linguistic dating the core LBH books are described in terms of what distinguishes LBH from EBH but this is only a relatively thin layer of the language of these books. Of the late lexemes mentioned above, the early alternatives of ישט and

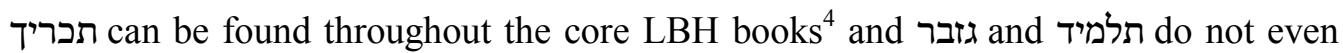
have clear early alternatives. ${ }^{5}$ This makes that there is hardly any contrast between EBH and LBH concerning these features. ${ }^{6}$

An approach that does justice to both continuity and change in Biblical Hebrew (BH) should take into consideration as much data as possible. Electronic editions of the Hebrew Bible and other ancient literature are an important tool for studying the Hebrew Bible and to collect the data. Several packages are available for doing queries in its text. In this article we use the tools of the open source SHEBANQ project.

2 We have described this problem earlier in Rezetko and Naaijer (2016).

3 These late lexemes can all be found in Hurvitz (2014), in which these lexemes are described as being typical of LBH.

4 ישט,, according to Hurvitz (2014:133). This early alternative is found in the LBH books in Est 2:21, 3:6, 6:2, 8:7, 9:2, 9:10, 9:15, 9:16, Dan 11:42, Neh 13:21, 1Chron 13:9 and 13:10.

5 Hurvitz (2014:79, 239). The early alternative of בגד is (Hurvitz 2014: 237), which can be found in LBH in Est 4:1, 4:4, Ezra 9:3, 9:5, Neh 4:17 and 2 Chron 18:9, 18:29, 23:13, $34: 19,34: 22,34: 27$.

6 More on this issue is described also Rezetko and Naaijer (2016). 


\section{Open source tools and the ETCBC database}

There is an important requirement that accompanies the use of digital methods in scholarly research: they should not diminish the transparency of the ways that hypotheses are confirmed or rejected. Moreover, computations that lead to new results should be replicable by other scholars. For this reason, it is as essential to publish the data and digital tools as it is important to publish the articles in which the conclusions are stated and discussed. Replication of results obtained by software is not easy in general, because the digital world is in constant flux and all software goes from version to version. To lower the barrier for effective replication we take care that our data are properly archived and our software is available as Open Source in online repositories with versioning. These resources can then be referenced in a persistent way, e.g., through Digital Object Identifiers (DOIs), and they can be freely downloaded.

We base our research on the database of the Eep Talstra Centre for Bible and Computer (ETCBC). A few years ago this database was brought fully online as a research tool in the form of SHEBANQ (System for HEBrew text: Annotations for Queries and markup). On the SHEBANQ website, ${ }^{7}$ one can read the complete Masoretic Text according to Biblia Hebraica Stuttgartensia. ${ }^{8}$ More importantly, SHEBANQ adds the morphological and syntactic encoding of the ETCBC database in such a way that the user can perform queries on that information.

Much of the information that underlies the present article has been gathered by means of queries in SHEBANQ. With a query one can search for words, phrases, clauses or combinations of these with specific lexical, morphological or syntactic characteristics. These queries have been published and will not change anymore. Even if newer versions of the ETCBC database arrive, it will continue to be possible to view the original list of results in the original version of the data.

Together with the construction of SHEBANQ, two things have been achieved: (i) a research tool has been built to deal with all facets of Hebrew text and data

7 https://shebanq.ancient-data.org.

8 It contains the text of the fourth edition of $B H S$. In the future we plan to add the text of Hebrew inscriptions, biblical and non-biblical Dead Sea Scrolls. 
LAF-Fabric has been superseded by Text-Fabric

processing: LAF-Fabric; (ii) all relevant resources have been archived and can be downloaded and re-used. We refer to van Peursen et al. (2015) for the data, to Roorda (2015a) for the SHEBANQ software, and to Roorda (2015b) for LAF-Fabric and supporting tools. ${ }^{9}$ This makes it possible to reconstruct the whole SHEBANQ later, in case the current website goes out of service. The history of the Hebrew Text database is told in Roorda (2015c) and more about the underlying models for processing text and data can be found in Roorda and van Peursen (2016).

\section{Object clauses in Biblical Hebrew}

In the rest of this article we re-evaluate scholarly literature on variation in the structure of the object clause using the tools described above.

The object clause is a complete clause which functions as the object of a transitive verb. Very often this transitive verb is a verb of saying (like צוה or נגד or a verb of perception (like ראה or). ${ }^{10}$ In this paper we discuss two different linguistic features related to the object clause in MT Hebrew. In section 2 we study the phrase order in the verbless object clause, and in section 3 the variation between כשר כי introducing the object clause is analysed. In most studies related to linguistic dating of biblical texts the focus is on the late variants occurring in the LBH texts because these are the items that are thought to make it possible to date biblical texts linguistically. However, in most cases, early variant(s) are found in LBH texts and the late variant(s) are found in EBH texts. This does not necessarily reduce the value of the feature for diachronic investigations, but it makes it necessary to study both the early and late variants throughout the MT, in order to make a balanced evaluation of the distribution of both variants, after which one can get a clearer impression of similarities and differences between EBH and LBH.

\footnotetext{
9 An overview of all sources is available at https://shebanq.ancient-data.org/sources.

10 Gesenius and Kautzsch (1910:§157), Joüon \& Muraoka (2006:§157).
} 


\section{PHRASE ORDER AND RABBINIC HEBREW}

In Esther 3.4 one can find the following object clause:

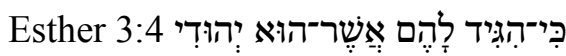

Here the complementiser אשר is followed by a personal pronoun subject and a nominal predicate. It is an unusual instance of an object clause in which the pronoun precedes the nominal predicate. ${ }^{11}$ Some examples of the standard pattern are:

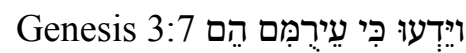

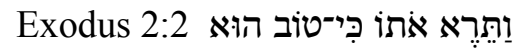

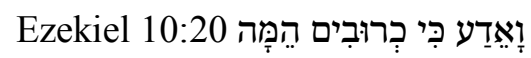

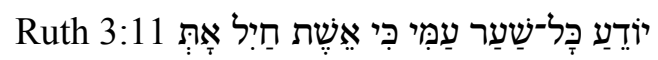

The specific order in Esther 3:4 is characteristic of Rabbinic Hebrew and according to some this example can be seen as a forerunner of the Mishnaic use (Bergey 1983:72, Sáenz-Badillos 1993:126-127). This is an indication of the diachronic development of Biblical Hebrew (Bergey 1983:72).

To get a more general impression of the this feature, we made a SHEBANQ query that searches for all clauses introduced by אשר or, followed by a subject personal pronoun and then a nominal predicate. ${ }^{12}$ The list of results contains all the cases of the fixed expression כי אני יהוה and its variations, but besides that it also contains at least two object clauses in the Pentateuch and Former Prophets:

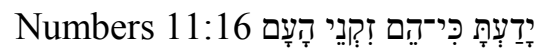

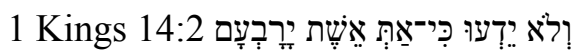

Besides the case of Esther 3:4, this construction is absent in the core late books of Esther, Daniel, Ezra, Nehemiah and Chronicles, which means that there is not only a sporadic use of this word order in the Late Biblical Hebrew books, but likewise there is a sporadic use in the EBH books. This makes it more likely that this is simply a rare feature in MT Hebrew than that the case in Esther 3:4 is a clear forerunner of Mishnaic Hebrew.

11 This clause in Esther 3:4 is also unusual in the sense that the complementiser is of $כ$, but that characteristic is discussed in the next section.

12 The result is available at https://shebanq.ancient-data.org/hebrew/query?version= $4 \mathrm{~b} \& \mathrm{id}=1093$. The actual query instruction and an explanation can also be found there. 


\section{אשר/כי THE OBJECT CLAUSE INTRODUCED BY}

\section{Introduction}

A linguistic construction characteristic of Late Biblical Hebrew that has often been cited in the literature on diachrony in Biblical Hebrew is the variation between כי כa introducing the object clause. ${ }^{13}$ In most cases in the MT כשר is used, but sporadically אשר can be found with the same function, e.g.,

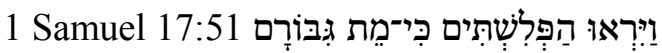

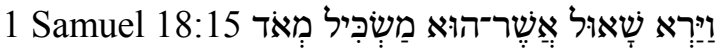

In LBH, especially in the books of Esther and Nehemiah, there is an increase of the משר ane and a decrease of the use of בשר (BDB s.v, Bergey 1983:61-64, Polzin 1976:128, Rooker 1990:111-112).

To be able to study the variation between משר introducing the object clause we created a dataset with the help of LAF-Fabric containing object clauses introduced by and אשר ${ }^{14}$

\section{אשר introducing the object clause in the book of Ezekiel}

According to Rooker (1990:111-112), the use of אשר in Ezekiel 20:26 can be seen as a sign of the diachronic change of Ezekiel's language, which he illustrates by comparing this clause with the object clause in Exodus 8:18:

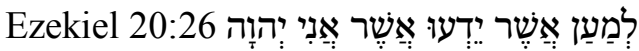

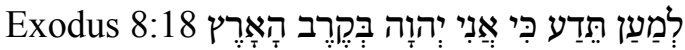

Exodus uses the early alternative כי כידע מith the same matrix verb is the this is a clear contrasting case, but this approach has several problems. In the first place, it is easy to find a very similar example in Exodus with ידע in which אשר is used:

13 We distinguish these cases of the object clause from clauses introduced by את אשר. Holmstedt (2001:5) calls these cases of a "headless relative in the object position". We do not consider them in this paper. Some examples can be found in Gen 27:45, 30:29 and 41:25. Note that this type of clause can also be found with אשר only, for instance in Gen $18: 17,39: 23,41: 28$.

14 The dataset with complete description can be found at https://github.com/MartijnETCBC/ ObjectClause. We refer to this dataset as the object_clause_dataset. 


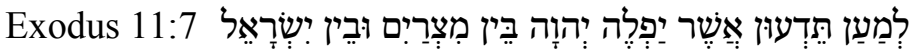

It is not so obvious that this is a sign of diachronic change in the language of the book of Exodus. Further, the case of אשר in Ezekiel 20:26 is the only example of the use of כי ו אשר in the book of Ezekiel. Instead of very often in this book, not only in the fixed expression כי אני יהוה, but also in other expressions with the transitive verbs ראה in the main clause:

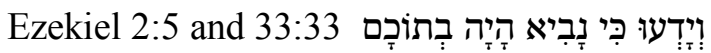

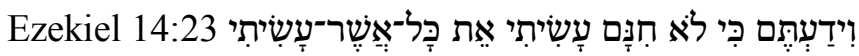

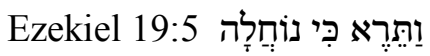

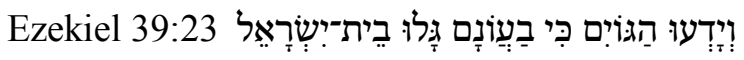

Similar constructions using the same transitive verbs are attested frequently throughout the Hebrew Bible.

כי From these observations one can conclude that the pattern of variation between and in the book of Ezekiel is similar to the pattern in most of the books written in Early Biblical Hebrew: there is a single exceptional case of אשר and more cases of, from which we can conclude that Ezekiel does not display the supposed pattern of Late Biblical Hebrew, but that of Early Biblical Hebrew.

\section{and ate Biblical Hebrew}

Now we have a look at the object clauses introduced by אשר in Late Biblical Hebrew. First we have a look at the object_clause_dataset. There is a huge difference between the number of object clauses introduced by כשר and and The dataset contains 527 clauses introduced by כי ביר and only 26 clauses introduced by introduced by כידע (281x or 53\%), ראה (133x or 25\%) or שמע (60x or 11\%).

According to Bergey there is an increased use of אשר in Late Biblical Hebrew, which is visible especially in the books of Esther and Nehemiah. ${ }^{15}$ He says

15 In LBH there are cases with אשר in Est 1:19, 2:10, 3:4, 4:11, 8:11, Dan 1:8 (2x), Ezra 2:63 (=Neh 7:65), Neh 7:65, 13:19, 13:22, 2 Chron 2:7, 18:15. 
disuse in later sources (Bergey 1983:62), which he illustrates with some examples in Rabbinic Hebrew in which $-ש$ is used as complementiser.

A closer look at the dataset shows that the hypothesis that was in the process of being replaced by אשר needs some correction. In the first place, we can find examples of object clauses introduced by כי וn all the core LBH books. אשר is relatively rare in the book of Chronicles ${ }^{17}$ and in the non-biblical Dead Sea Scrolls כ is used generally. ${ }^{18}$ Although the evidence is sparse, and van Peursen (2004:301-304) finds only clear examples of object clauses introduced by כשר in Ben Sira. It is true that is used relatively often in Esther and Nehemiah, but there is no complete replacement

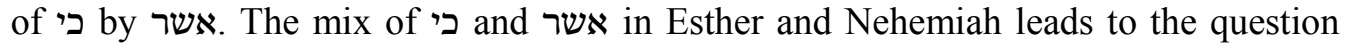
whether the choice between אשר and completely random in these books. There might be some difference in the environment of the particle that conditions the choice of the particle.

A look at the object_clause_dataset shows that, when the object clause is introduced by אשר and in ראה ,ידע in in only in relatively few cases with the verbs and often with verbs otherwise not found with object clauses, like שקש, (both in Dan 1:8), צוה (Est 1:19) and 2:10). It is also interesting that the clauses introduced by in LBH are nearly all governed by the most occurring transitive verbs שמע and is a pity that, since we have only relatively few clear cases of אשר functioning as a complementiser in the MT, there is insufficient evidence to draw clear conclusions.

Does the variation between אשר and מי כי have diachronic significance? It is true that those books in which the non-standard pattern is found are all post-exilic books. On the other hand, the standard pattern with כי continues to be used throughout post-exilic BH and in the Dead Sea Scrolls, so there is no clear sign of its "disuse". Polzin (1976:128) suggests that it might be a dialectical feature. In itself this is an interesting suggestion, but the evidence for it is as scant as for the claim that it is a sign of

16 Esther 3:5, 7:7, Dan 8:17, Ezra 4:1, Neh 3:33, 4:1, 4:9, 6:16, 9:10, 13:10, 1 Chron 10:5, $10: 7,14: 2,14: 8,18: 9,19: 6,19: 10,19: 15,19: 16,19: 19,21: 18,21: 28,28: 10,29: 17,2$ Chron 6:33, 12:7, 13:5, 15:9, 18:32, 20:29, 22:10, 24:11, 25:16, 28:23, 32:2, 33:13.

172 Chronicles $2: 7$ and 18:15.

18 Bergey (1983:62) gives the examples using כי in 1QS 10:16, 1QH 4:30 and CD 1:8. 
diachrony in BH. Holmstedt (2016:216-225) describes the history of clauses introduced by אשר. He concludes that in epigraphic Hebrew and in the non-biblical Dead Sea Scrolls אשר introduces relative clauses and no object clauses, generally like it does in BH. Perez Fernandez (1999: 50) states that אשר is used in Rabbinic Hebrew exclusively in biblical quotations and liturgical texts, from which Holmstedt (2016:223) concludes that it is "diachronically fascinating, that the Mishnah evinces neither the complementiser nor any other nonrelative function of אשר". This positioning of the function of אשר within the history of the Hebrew language makes it even more implausible to speak about a gradual replacement of the early variant כי by the late variant אשר.

We believe it is realistic to say that the variation between משר androducing the object clause concerns a substandard construction in the MT, which is visible mainly in the core LBH books, but which exists next to the standard כי. It may very well be correct that the relative function of אשר is older than its function as introductory particle of object clauses. But in this latter function its rare attestation outside the core LBH books makes it less useful for linguistic dating of biblical texts of unknown date.

\section{CONCLUSIONS}

In this article we discussed the way the object clause has been studied from the perspective of diachronic change in MT Hebrew. For our analyses we have made use of the open source database of the Eep Talstra Centre for Bible and Computer. We have studied three classes of phenomena which have been used to attest a transition from Early to Late Biblical Hebrew, and found the evidence lacking in all three cases. The first case is the specific order of pronominal subject followed by a nominal predicate in Esther 3:4, which is rare in the Hebrew Bible but common in Mishnaic Hebrew. It is more likely that this is simply an uncommon linguistic feature in the Masoretic Text than that it has diachronic significance, because this word order can be 
found in object clauses in Early Biblical Hebrew, as we have shown with the help of our SHEBANQ query.

Secondly, a similar case is the supposed diachronic significance of the object clause introduced by אשר in Ezekiel 20:26. The object clause introduced by אשר can be found once in Ezekiel, which is comparable with several EBH books. Finally we studied the variation between משר in the core narrative LBH books. In these books there is a continuity of the use of כי, but there is also a substandard use of object clauses introduced by אשר. These object clauses have a tendency to be governed by other transitive verbs than those that are used generally with object clauses introduced by כי

Although it is difficult to draw strong conclusions based on a relatively small amount of data from an ancient corpus with all its limitations, it is clear that by the use of digital versions in which one can search for morphological and syntactic features, it is possible to make steps forward in the study of the history of Biblical Hebrew. The work by Rezetko and Young (2014) provides a useful theoretical background for further study, of which this article is just one example.

\section{BIBLIOGRAPHY}

Bergey, R L 1983. The book of Esther-its place in the linguistic milieu of post-exilic Biblical Hebrew prose: a study in Late Biblical Hebrew. $\mathrm{PhD}$ dissertation. Dropsie College for Hebrew and Cognate Learning.

Brown, F, Driver, S R and Briggs, C A 1907. A Hebrew and English lexicon of the Old Testament. Oxford: Clarendon. (BDB)

Gesenius, W and E Kautzsch, 1910. Hebrew grammar. Trans. Cowley AE. Oxford: Oxford University Press.

Holmstedt, R D 2001. Headlessness and extraposition: another look at the syntax of רש, JNSL 27/1:1-16.

2016. The relative clause in Biblical Hebrew. Winona Lake: Eisenbrauns.

Hurvitz, A 1974. The date of the prose-tale of Job linguistically reconsidered, HTR 67:17-64.

1982. A linguistic study of the relationship between the Priestly source and the book of Ezekiel : a new approach to an old problem. CahRB 20. Paris: J. Gabalda.

Hurvitz, A, in collaboration with Gottlieb, L, Hornkohl, A and Mastéy, E, 2014. A 
Concise lexicon of Late Biblical Hebrew, linguistic innovations in the language of the Second Temple Period. Leiden: Brill.

Joüon, P and T Muraoka 2006. A grammar of Biblical Hebrew. Translated and revised by T. Muraoka. SubBi 27. 2nd ed. Rome: Pontifical Biblical Institute.

Pérez Fernandez, M 1999. An introductory grammar of Biblical Hebrew. Translated by J Elwolde. Leiden: Brill.

Polzin R 1976. Late Biblical Hebrew: toward an historical typology of Biblical Hebrew prose. Missoula, MT: Scholars Press.

Rendsburg, G A 1990a. Diglossia in ancient Hebrew. American Oriental Series 72. New Haven: American Oriental Society. 1990b. Linguistic evidence for the northern origin of selected Psalms. Society of Biblical Literature Monograph Series 43. Atlanta: Scholars Press. 2002. Israelian Hebrew in the Book of Kings. Occasional Publications of the Department of Near Eastern Studies and the Program of Jewish Studies, Cornell University 5. Bethesda, MD: CDL Press.

Rezetko, R and Naaijer, M 2016, An alternative interpretation of the lexicon of Late Biblical Hebrew, The Journal of Hebrew Scriptures 16, Article 1, Available: http://jhsonline.org/Articles/article_213.pdf. [Accessed 2016/10/01.]

Rezetko, R \& Young, I 2014. Historical linguistics and Biblical Hebrew, steps toward an integrated approach. ANEM 9. Atlanta: SBL Press.

Rooker, M F 1990. Biblical Hebrew in transition: the language of the book of Ezekiel. JSOTSup. 90. Sheffield: Sheffield Academic Press.

Roorda, D 2015a. SHEBANQ software. Github. https://github.com/ETCBC/shebanq. Snapshot archived at Zenodo: http://dx.doi.org/10.5281/zenodo.33093. 2015b. LAF-Fabric software. Github. https://github.com/ETCBC/laf-fabric. Snapshot archived at Zenodo: http://dx.doi.org/10.5281/zenodo.33091. 2015c. 'The Hebrew Bible as Data: Laboratory Sharing - Experiences' http://arxiv.org/abs/1501.01866 https://github.com/ETCBC/text-fabric

Roorda, D and van Peursen, W Th 2016. The Hebrew Bible as data: text and annotations. To be published in the DIXIT proceedings (http://dixit.huygens.knaw.nl).

Sáenz-Badillos, A 1993. A history of the Hebrew language. Translated by J. Elwolde, Cambridge: Cambridge University Press.

Van Peursen, W Th, 2004. The verbal system in the Hebrew of Ben Sira. Leiden: Brill. Van Peursen, W Th, Sikkel, C and Roorda, D 2015. Hebrew text database ETCBC4b. Dataset archived at DANS. DOI: http://dx.doi.org/10.17026/dans-z6y-skyh.

Young, I, Rezetko, R and Ehrensvärd, M 2008. Linguistic dating of biblical texts. 2 volumes. London: Equinox Publishing. 